KS. RAFAŁ KAMIŃSKI CSMA

Wydział Prawa Kanonicznego

Uniwersytetu Kardynała Stefana Wyszyńskiego w Warszawie

\title{
REFORMA PAPIESKICH INSTYTUCJI DO SPRAW KOMUNIKACJI SPOŁECZNEJ
}

Treść: Wstęp. - 1. Działania Papieskiej Komisji w okresie przedsoborowym. - 2. Zadania Komisji związane z przygotowaniem i obradami Soboru Watykańskiego II. - 3. Zmiany dokonane przez papieża Pawła VI. - 4. Powstanie i działalność Papieskiej Rady Środków Społecznego Przekazu. 5. Reforma Papieża Franciszka. - 5.1. Organizacja pracy Sekretariatu do spraw Komunikacji. - 5.2. Szczegółowe kompetencje wydzielonych komórek. - 5.3. Pracownicy i współpracownicy Sekretariatu do spraw Komunikacji. - 5.4. Normy przejściowe. - Zakończenie.

\section{Wstęp}

Pojawianie się coraz nowszych środków komunikacji społecznej (co ściśle wiąże się z dynamiką jej rozwoju), wymagało na przestrzeni historii i nadal wymaga od Kościoła zajęcia właściwego stanowiska. Nauczycielski Urząd Kościoła realizuje to zadanie przede wszystkim przez redakcję odpowiednich dokumentów Magisterium. Innym ważnym działaniem w tym obszarze było tworzenie specjalnych instytucji, które w strukturach Kurii Rzymskiej bezpośrednio zajmowały się problematyką mediów. Do roku 2015 zadanie to wypełniała Papieska Rada Środków Społecznego Przekazu, od roku 1948 przeżywająca ewolucję, w której można wyróżnić trzy główne etapy.

Początkowo zadanie to podejmowała poprzedzająca Radę Komisja, która przez kilkanaście lat podlegała ciągłym modyfikacjom (od 1948 do 1964 roku), natomiast od 1964 do 2015 roku działała Papieska Rada 
Środków Społecznego Przekazu1. Ostatnim reformatorskim akcentem na tym polu jest Sekretariat do spraw Komunikacji, który 27 czerwca 2015 roku powołał Papież Franciszek.

Celem niniejszego studium jest prezentacja papieskich instytucji do spraw komunikacji społecznej, obejmująca ich historyczny rozwój, a także reformowane kilkakrotnie struktury.

\section{Działania Papieskiej Komisji w okresie przedsoborowym}

Pierwszym organem zajmującym się środkami społecznej komunikacji o charakterze centralnego urzędu katolickiego była ustanowiona 20 stycznia 1948 roku Międzynarodowa Komisja do spraw Konsultacji i Badania Filmów o Tematyce Religijnej ${ }^{2}$. W celu badania dzieł filmowych mających ilustrować naukę chrześcijańską Pius XII utworzył ten nowy urząd ad experimentum, nadając mu następnie nazwę Papieskiej Komisji do spraw Kinematografii Dydaktycznej i Religijnej, jako konkretny i praktyczny wyraz ducha encykliki Vigilanti cura ${ }^{3}$. Papież zatwierdził także Statut nowej Komisji o charakterze międzynarodowym, która otrzymała siedzibę w Watykanie.

Z okazji dwudziestej piątej rocznicy powstania tego organu Kurii Rzymskiej ówczesny bp A. M. Deskur napisał, że „Papieska Komisja do spraw Kinematografii Dydaktycznej i Religijnej, dostrzegłszy złożoność problemów edukacyjnych i pastoralnych rodzącej się epoki audiowizualnej, bardzo szybko stwierdziła (...), iż aby być duszpastersko użyteczną (...), powinna podjąć studium problemów kina (...) w zmieniających się warunkach społeczeństwa"4.

${ }^{1}$ Por. P. Duźniak, Il Pontificio Consiglio delle Comunicazioni Sociali: storia, struttura e funzioni, Roma 1991, s. 53.

2 Por. Secretaria Status, Litterae n. 163 561, 20 stycznia 1948, Archivio del PCCS (mps). (PCCS jest skrótem od włoskiej nazwy Papieskiej Rady Środków Społecznej Komunikacji).

${ }^{3}$ Por. Secretaria Status, Litterae n. 181 921, 17 września 1948, Archivio del PCCS (mps).

${ }^{4}$ A. M. Deskur, Il venticinquesimo della Pontificia Commissione per le Comunicazioni Sociali, „L’Osservatore Romano” 213 (1973), s. 1. 
Statut Komisji stwierdza, że będzie ona działać w stałej współpracy z krajowymi katolickimi instytutami filmowymi, które będą zapraszane, aby przedstawiać roczne sprawozdania ze swojej działalności. Kolejne zarządzenie dotyczy tematów filmowych, które mają być przedstawiane Komisji za pośrednictwem lokalnych katolickich instytutów filmowych, uznawanych przez kompetentne władze kościelne ${ }^{5}$.

Papieska Komisja do spraw Kinematografii Dydaktycznej i Religijnej 1 stycznia 1952 roku została przekształcona w Papieską Komisję do spraw Kinematografii, której dodatkowym zadaniem była analiza filmów mających związek z wiarą i moralnością. Do tego zadania zostali powołani specjaliści z różnych krajów. Od 10 grudnia 1952 roku Komisja rozpoczęła publikację dwumiesięcznika „Bulletin d'informations” w języku francuskim, który był przeznaczony głównie dla jej członków. W tym okresie zauważa się ścisłą współpracę Papieskiej Komisji do spraw Kinematografii z Międzynarodową Katolicką Organizacją Filmową (OCIC) oraz z narodowymi katolickimi ośrodkami filmowymi, utworzonymi przez hierarchię w różnych krajach ${ }^{6}$.

W 1954 roku nazwa Komisji ponownie uległa zmianie. Z powodu rosnącej wrażliwości na problemy w różnych mediach zadania i pracę Komisji rozszerzono także na radio i telewizję. Nastąpiło to wraz z wydaniem nowego Statutu zmienionej Komisji, który 16 grudnia 1954 roku zatwierdził Pius XII7 . Statut ten był wielkim krokiem naprzód w kwestii odpowiedzialności organizacyjno-pastoralnej ze strony centralnego zarządu Kościoła. Trzy lata później ukazała się bardzo ważna z punktu widzenia działalności środków społecznej komunikacji encyklika Miranda prorsus. Papież powierzył Komisji wykonanie zawartych w niej rozporządzeń, które dotyczyły problemów

${ }_{5}$ Por. PIUs XII, Statuto della Pontificia Commissione per la Cinematografia Didattica e Religiosa, 1948, Archivio del PCCS (mps), s. 4.

6 Por. P. Duźniak, Il Pontificio Consiglio delle Comunicazioni Sociali..., dz. cyt., s. 50 .

7 Por. Secretaria Status, Acta Officiorum, AAS 46 (1954), s. 783-784. 
związanych z wiarą, moralnością i dyscypliną kościelną w sektorach: radia, telewizji i kina ${ }^{8}$.

22 lutego 1959 roku Komisja otrzymała nowe kompetencje przyznane jej przez motu proprio Boni Pastoris, w myśl którego miała ona mieć „charakter stały jako urząd Stolicy Świętej do badania, rozwijania i kierowania różnych aktywności w dziedzinie kina, radia i telewizji", ze szczególnym uwzględnieniem klasyfikacji moralnej filmów, transmisji radiowych i telewizyjnych o charakterze religijnym oraz pouczania wiernych, zwłaszcza młodzieży, w kwestii obowiązków chrześcijańskich w odniesieniu do widowisk. Na mocy tego samego motu proprio zarządzono, że „Kongregacje Kurii Rzymskiej i inne urzędy Stolicy Świętej będą pytać Komisję o zdanie przed wydaniem rozporządzeń lub udzieleniem zezwoleń dotyczących dziedzin kina, radia i telewizji, a także będą informować tę Komisję o środkach podjętych w ramach przysługujących im kompetencji"10.

\section{Zadania Komisji związane z przygotowaniem i obradami Soboru Watykańskiego II}

Przy okazji przygotowań do zwołanego przez siebie soboru papież Jan XXIII wydał motu proprio Superno Dei nutu, ustanawiając jedną Komisję Centralną oraz komisje przygotowawcze Soboru Powszechnego Watykańskiego II, dla których został zaplanowany odpowiedni program działania. Wśród nich utworzony został Sekretariat

8 Pius XII, Litterae Encyclicae Miranda prorsus, 8 września 1957, AAS 49 (1957), S. 805 .

9 IoAnnes XXIII, Litterae Apostolicae Boni Pastoris, AAS 51 (1959), s. 185: „Nos igitur decernimus ac definimus, ut Pontificium Consilium rei cinematographicae, radiophonicae ac televisificae praepositum sit firmum ac stabile institutum ut Sedis Apostolicae Officium, cui id propositum sit, ut varias de re cinematographica, radiophonica ac televisifica quaestiones examinet".

10 Tamże, s. 186: „Sacrae autem Romanae Curiae Congregationes ceteraque Sedis Apostolicae Officia hoc Consilium rogent sententiam, antequam aliquid decernant iubeantque vel quidlibet agendi potestatem faciant, quod ad rem cinematographicam, radiophonicam ac televisificam attineat, atque idem Consilium de praeceptionibus, quas pro sua cuiusque auctoritate dederint, certius reddant". 
Przygotowawczy Soboru dla Prasy i Widowisk z siedzibą przy Papieskiej Komisji ${ }^{11}$. Komisja Centralna wniosła ważny wkład w działalność Sekretariatu, oddając mu do dyspozycji aktualny materiał informacyjny o nowoczesnych technikach przekazu w świecie, a także dokumenty o charakterze teologicznym, prawnym i pastoralnym, opracowane dla Komisji przez wybitnych specjalistów. „Skuteczny wkład w prace Sekretariatu znalazł wyraz w prezentacji ojcom soborowym schematu De Instrumentis Communicationis Socialis"12.

Wreszcie zadanie o historycznym znaczeniu zostało powierzone komisji ojców Soboru Watykańskiego II podczas XXVIII Kongregacji Generalnej z okazji zakończenia dyskusji soborowej nad wspomnianym schematem. Ojcowie soborowi, jak stwierdza numer 57 tego dokumentu, „poprosili papieża, aby zechciał rozszerzyć kompetencje Papieskiej Komisji do spraw Kinematografii, Radia i Telewizji na wszystkie środki komunikacji społecznej, włącznie z prasą"13.

Dekret soborowy Inter mirifica o środkach komunikacji społecznej przewiduje również utworzenie przy Stolicy Świętej specjalnego biura do spraw tychże środków ${ }^{14}$, zlecając mu przygotowanie tekstu

11 Secretaria Status, Diarium Romanae Curiae, AAS 52 (1960), s. 579.

12 P. Duźniak, Il Pontificio Consiglio delle Comunicazioni Sociali..., dz. cyt., s. 70.

13 Acta Synodalia Sacrosancti Concilii Oecumenici Vaticani II, t. I, cz. 3, Città del Vaticano 1971, s. 398: „Patres Concilii vero, votum »Secretariatus de Scriptis prelo edendis et de Spectaculis moderandis« libenter excipientes, Summum Ponteficem reverenter rogant ut huius Officii munera et competentia ad omnia communicationis socialis instrumenta, prelo non excepto, extendatur".

${ }^{14}$ Por. Concilum Vaticanum II, Decretum de instrumentis communicationis socialis Inter mirifica, 4 grudnia 1963, AAS 56 (1964), n. 19. Tekst polski: SoвóR WATYкАŃsKI II, Dekret o środkach społecznego przekazu Inter mirifica, 4 grudnia 1963 w: Tenże, Konstytucje - Dekrety - Deklaracje, Poznań 2012, n. 19. Chodzi o urząd, który zajmuje miejsce Papieskiej Komisji do spraw Kina, ustanowionej przez Piusa XII w 1948 roku (por. SECRETARIA StATUs, Litterae n. 163 561, dz. cyt.) i rozciągniętej na radio i telewizję w 1954 roku (por. Secretaria Status, Acta Officiorum, dz. cyt., 783-784). Krótko przed Soborem, w 1959 roku, Jan XXIII uporządkował ją na nowo (por. IoAnnes XXIII, Litterae Apostolicae Boni Pastoris, dz. cyt., s. 183-187), a Paweł VI w roku 1964 ustanowił Pontificia Commissio de Communicationibus Socialibus (por. PAOLO VI, Litterae Apostolicae In fructibus multis, 2 kwietnia 1964, AAS 65 
późniejszej instrukcji w celu zastosowania norm i zasad wspomnianego dekretu. Sobór postanowił także stworzyć organy podobne do Papieskiej Komisji na różnych poziomach kościelnych dla ulepszenia posługi apostolskiej na płaszczyźnie krajowej i międzynarodowej. Inter mirifica domaga się ponadto powołania krajowych biur do spraw mediów (w których mogą pracować także świeccy) pod przewodnictwem komisji biskupiej lub oddelegowanego biskupa. Dekret stanowi również, że międzynarodowe organizacje katolickie, prawowicie zatwierdzone przez Stolicę Świętą i zależne od niej, powinny koordynować różne działania dotyczące środków komunikacji społecznej w wymiarze międzynarodowym ${ }^{15}$.

\section{Zmiany dokonane przez papieża Pawła VI}

Paweł VI w motu proprio In fructibus multis z 2 kwietnia 1964 roku zmienił nazwę dotychczasowej Komisji na Papieską Komisję do spraw Komunikacji Społecznej, powierzając jej to, „co dotyczy interesów religii katolickiej, problemów związanych z kinem, radiem i telewizją, jak również prasą codzienną i periodyczną"16. Zarządził ponadto, że Komisja zostaje przyłączona do Sekretariatu Stanu. Podobnie jak poprzednia, nabrała ona również charakteru kolegialnego i szeroko reprezentatywnego. Instytucja otrzymała „Regulamin dotyczący rejestracji audiowizualnych ceremonii i miejsc bezpośrednio zależnych od Stolicy Świętej”, zatwierdzony 13 sierpnia 1965 roku przez Ojca

(1964), s. 289-292). Następnie została ona przemianowana na Pontificium Consilium de Communicationibus Socialibus przez Jana Pawła II (por. IoAnnes Paulus II, Constitutio Apostolica de Romana Curia Pastor Bonus, 28 czerwca 1988, AAS 80 (1988), art. 169. Tekst polski: Jan PAwe£ II, Konstytucja apostolska o kurii rzymskiej Pastor Bonus, 28 czerwca 1988, w: Dzieła zebrane, t. IV: Konstytucje apostolskie, listy motu proprio i bulle, orędzia na światowe dni, Kraków 2007, art. 169.

15 Por. Soвór Watykański II, Dekret o środkach społecznego przekazu Inter mirifica, dz. cyt., n. 23.

16 Paulus VI, Litterae Apostolicae In fructibus multis, dz. cyt., s. 291: „Cuius curae, si causa perpendatur catholicae religionis, demandamus res cinematographicas, radiophonicas et televisificas, atque scripta typis vel cotidie vel per intervalla edita". 
Świętego, który zlecił jej badanie wniosków i wystawianie ewentualnych zezwoleń w tej dziedzinie ${ }^{17}$.

Komisji powierzono także troskę o Biuro Prasowe Stolicy Świętej, utworzone w następnym roku, oraz kierowanie i zarządzanie Filmoteką Watykańską. Struktura i kompletność Komisji zostały zatwierdzone przez konstytucję apostolską Regimini Ecclesiae Universae $\mathrm{z} 15$ sierpnia $1967 \mathrm{roku}^{18}$.

W 1971 roku ukazała się - bardzo istotna dla omawianego zagadnienia - instrukcja duszpasterska Communio et progressio, którą Komisja opracowała zgodnie z wyraźnym życzeniem Soboru Watykańskiego $\mathrm{II}^{19}$. Po jej promulgacji instytucja ta natychmiast podjęła wysiłki w celu realizacji w całym Kościele wytycznych zawartych w nowym dokumencie ${ }^{20}$.

Papieska Komisja do spraw Środków Społecznego Przekazu razem z Sekretariatem Stanu intensywnie pracowała nad rozpowszechnianiem dokumentów Magisterium i informowaniem o różnych działaniach apostolskich papieża; podjęła także współpracę z innymi dykasteriami Kurii Rzymskiej. W tym okresie co roku odbywały się jej zebrania plenarne. Syntetycznie rzecz ujmując, analizowano i studiowano problemy dotyczące mass mediów w wymiarze ogólnym, ze

17 Por. Pontificium Consilium de Communicationibus Socialibus, Regolamento per le riprese audiovisive delle cerimonie e dei luoghi direttamente dipendenti dalla Santa Sede, 13 sierpnia 1965 roku, Archivio del PCCS (mps), art. 7.

18 Por. Paulus VI, Constitutio Apostolica Regimini Ecclesiae Universae, 15 sierpnia 1967, AAS 59 (1967), art. 133.

19 Pontificium Consilium Instrumentis Communicationis Socialis, Instructio pastoralis Communio et progressio ad decretum Concilii Oecumenici Vaticani II de instrumentis communicationis socialis rite applicandum de mandato eiusdem concilii exarata, 23 maja 1971, AAS 63 (1971), s. 595-656. Tekst polski: PAPIEsKA Komisja Środków Społecznego Przekazu, Instrukcja pastoralna $z$ dnia 23 maja 1971 roku o środkach społecznego przekazu „Communio et progressio”, w: F. Adamski (red.), Kościót a kultura masowa, Kraków 1984, n. 184-185.

20 Pontificium Consilium de Communicationibus Socialibus, Lettera, 8 maja 1971, Bollettino d'informazione 80 (1971), s. 41-43; Pontificium Consilium de Communicationibus Socialibus, Criteri di collaborazione ecumenica nelle comunicazioni sociali, 15 listopada 1971, Bollettino d'informazione 80 (1971), s. 65-68. 
szczególnym uwzględnieniem roli Papieskiej Komisji w apostolacie i działania na rzecz rozwoju za pośrednictwem nowoczesnych technik komunikacji społecznej ${ }^{21}$.

\section{Powstanie i działalność Papieskiej Rady Środków Społecznego Przekazu}

Pierwsze czterdziestolecie istnienia urzędu poświęconego mediom w strukturach centralnego zarządu Kościoła zakończyło się 28 czerwca 1988 roku, czyli w dniu promulgacji przez papieża Jana Pawła II konstytucji apostolskiej Pastor Bonus dotyczącej reformy Kurii Rzymskiej. W artykułach 169 i 17022, oprócz zmiany rangi i nazwy instytucji na Papieską Radę Środków Społecznego Przekazu postanowiono, że Rada pozostaje w ścisłym związku z Sekretariatem Stanu, pełniąc funkcję wzbudzania i wspierania odpowiedniego działania Kościoła i wiernych w rozmaitych formach komunikacji społecznej, aby zarówno dzienniki i inne periodyki, jak też widowiska filmowe,

${ }^{21}$ Por. P. Duźniak, Il Pontificio Consiglio delle Comunicazioni Sociali..., dz. cyt., s. 83.

${ }^{22}$ Jan PaweŁ II, Konstytucja apostolska o Kurii Rzymskiej Pastor Bonus, dz. cyt., art. 169-170: „Art. 169 \$1. Papieska Rada do spraw Środków Społecznego Przekazu zajmuje się sprawami dotyczącym środków społecznego przekazu w tym celu, aby również z ich pomocą rozszerzało się orędzie zbawienia i dokonywał się ludzki postęp zmierzający do rozwoju kultury i obyczajów. $\$ 2$. W wypełnianiu swojego zadania pozostaje w ścisłej łączności z Sekretariatem Stanu. Art. 170 \$1. Głównym zadaniem Rady jest pobudzanie i podtrzymywanie w odpowiedni sposób działalności Kościoła i wiernych w różnych formach środków społecznego przekazu; przyczynianie się do tego, by dzienniki oraz inne periodyki, filmy, przekazy radiowe i telewizyjne były coraz bardziej przepajane duchem ludzkim i chrześcijańskim. $\$ 2$. Szczególną troską Rada otacza katolickie pisma, periodyki, stacje radiowe i telewizyjne, ażeby rzeczywiście odpowiadały własnemu charakterowi i zadaniu, zwłaszcza przez przekazywanie doktryny Kościoła zgodnej z Magisterium, jak również przez właściwe i wierne rozpowszechnianie wiadomości religijnych. $\$ 3$. Utrzymuje łączność ze stowarzyszeniami katolickimi zajmującymi się środkami społecznego przekazu. $\$ 4$. Troszczy się o to, ażeby lud chrześcijański, zwłaszcza z okazji obchodów Światowego Dnia Środków Społecznego Przekazu, stawał się świadomy obowiązku, spoczywającego na każdym wiernym, podejmowania współpracy, by tego rodzaju środki służyły misji Kościoła”. 
transmisje radiowe i telewizyjne były coraz bardziej przeniknięte duchem ludzkim i chrześcijańskim. Ma ona ponadto otoczyć opieką katolickie środki komunikacji społecznej, „aby rzeczywiście odpowiadały własnej naturze i funkcji”. Rada powinna też „sprzyjać relacjom ze stowarzyszeniami katolickimi, które działają na polu komunikacji"23.

Dla lepszej formacji do apostolatu środków komunikacji społecznej Papieska Rada zawsze otaczała opieką i wspierała inicjatywy „zmierzające do coraz większego uwrażliwiania instytucji katolickich na problematykę związaną z informacją, radiem, telewizją, kinem"24.

Wśród rozlicznych aktywności Rady ważną rolę odegrały więc różne inicjatywy specjalne związane $\mathrm{z}$ wystąpieniami magisterialnymi i dyscyplinarnymi Kościoła w dziedzinie środków społecznej komunikacji, z których wyrosły nowe istotne dokumenty kościelne.

Szczególne miejsce w działalności Rady zajmuje przygotowanie i przeprowadzenie Światowego Dnia Środków Społecznego Przekazu. Został on ustanowiony dekretem Inter mirifica i od 1967 roku do dzisiaj jest obchodzony na całym świecie ${ }^{25}$. W czasie Światowego Dnia Środków Społecznego Przekazu nadrzędne stają się następujące elementy: modlitwa za dziennikarzy i innych pracowników mediów, wsparcie materialne kościelnych dzieł w tym zakresie oraz refleksja nad proponowanym co roku tematem, który kolejni papieże starają

\footnotetext{
${ }^{23}$ P. V. Pinto, Commento all'artt. 169-170, w: Tenże (red.), Commento alla „Pastor Bonus" e alle norme sussidiarie della Curia Romana, Roma 2003, s. 236.

${ }^{24}$ P. Monni, I laici e le comunicazioni sociali, Monitor Ecclesiasticus 1 (1983), s. 70.

25 Por. Sobór WATYKAŃski II, Dekret o środkach społecznego przekazu Inter mirifica, dz. cyt., n. 18. Światowy Dzień Środków Społecznego Przekazu to jedyne światowe obchody zalecone wprost przez Sobór Watykański II. Decyzją biskupów świata obchodzi się go w niemal wszystkich krajach w niedzielę poprzedzającą Zesłanie Ducha Świętego. Zapowiedź tematu następuje 29 września, w święto Archaniołów Michała, Rafała i Gabriela. Ten ostatni jest patronem pracowników radia. Tradycyjnie orędzie Ojca Świętego na Światowy Dzień jest podawane do wiadomości 24 stycznia, w dniu wspomnienia św. Franciszka Salezego, patrona dziennikarzy. Konferencje biskupie i biura diecezjalne mają w ten sposób czas na przygotowanie materiału potrzebnego do obchodów krajowych i lokalnych. Por. P. Duźniak, Il Pontificio Consiglio delle Comunicazioni Sociali..., dz. cyt., s. 161-163.
} 
się przybliżyć wiernym w przygotowywanych każdego roku specjalnych orędziach.

\section{Reforma Papieża Franciszka}

Pontyfikat obecnego Papieża od początku nacechowany jest troską o właściwy kontakt $\mathrm{z}$ wiernymi za pomocą środków społecznej komunikacji. Już trzeciego dnia po wyborze na Stolicę Piotrową Franciszek spotkał się z przedstawicielami mediów, przekonując ich: „Wasza praca (...) pociąga za sobą szczególną troskę o prawdę, dobro i piękno (...). Powinno być jasno widoczne, że wszyscy zostaliśmy wezwani nie do tego, by przekazywać nie siebie samych, ale tę egzystencjalną triadę, którą tworzą prawda, dobro i piękno"26.

Również w dotychczasowych orędziach na Światowy Dzień Środków Społecznego Przekazu Papież Franciszek dostrzega zarówno wielkie możliwości, jak i realne zagrożenia, które niosą ze sobą nowoczesne sposoby komunikacji. Ojciec Święty ma świadomość, że we współczesnym świecie, w którym sieci komunikacji międzyludzkiej osiągnęły niezwykle wysoki poziom rozwoju, media „(...) mogą nam pomóc poczuć się bliżsi jedni drugich, tworząc odnowione poczucie jedności ludzkiej rodziny, które pobudza do solidarności i do poważnego zaangażowania na rzecz bardziej godnego życia"27.

Papież Franciszek zwraca uwagę również na to, że o godziwości narzędzia komunikacji decyduje sposób jego użycia: „Także e-maile, SMS-y, sieci społecznościowe, czaty mogą być w pełni ludzkimi

\footnotetext{
${ }^{26}$ Franciscus, Discorso ai rappresentanti dei media, 16 marca 2013, http://www. vatican.va/holy_father/francesco/speeches/2013/march/documents/papa-francesco_20130316_rappresentanti-media_it.html (dostęp: 6 grudnia 2015). Tekst polski: Franciszek, Przemówienie do dziennikarzy Kościół ubogi i dla ubogich, 16 marca 2013, „L'Osservatore Romano” (wyd. pol.) 5 (2013), s. 12-13.

${ }^{27}$ Franciscus, Messaggio in occasione della XLVIII Giornata Mondiale delle Comunicazioni Sociali Comunicazione al servizio di un'autentica cultura dell'incontro, 24 stycznia 2014, http://www.pccs.va/index.php/it/giornate-mondiali-delle-comunicazioni-sociali/2014. (dostęp: 19 grudnia 2015 roku). Tekst polski: Franciszek, Orędzie na XLVIII Światowy Dzień Środków Społecznego Przekazu Przekaz w służbie kultury spotkania, 24 stycznia 2014, „L'Osservatore Romano” 2 (2014), s. 6.
} 
formami komunikacji. To nie technologia określa, czy komunikacja jest autentyczna, czy też nie, ale serce człowieka i jego zdolność do dobrego wykorzystania środków, jakimi dysponuje. Sieci społecznościowe mogą ułatwiać relacje i promować dobro społeczeństwa, ale mogą również prowadzić do dalszej polaryzacji i podziałów między ludźmi i grupami”28.

Zapowiadana przez Papieża Franciszka reforma Kurii Rzymskiej objęła także dykasterie odpowiedzialne za komunikację społeczną. Działająca przez ponad sześćdziesiąt lat Komisja, przekształcona z czasem w Papieską Radę, została wchłonięta przez utworzony 27 czerwca 2015 roku Sekretariat do spraw Komunikacji. Zmiana ta dokonała się poprzez ogłoszenie motu proprio L’attuale contesto comunicativo, w którym autor przekonuje, że nowe warunki komunikacji, w których dominuje rozwój digitalizacji i interaktywność, wymagają innego spojrzenia i reorganizacji struktur odpowiedzialnych za komunikację społeczną w Stolicy Apostolskiej, na rzecz ich większej współpracy i integracji.

Oprócz Papieskiej Rady Środków Społecznego Przekazu, w skład Sekretariatu zostały włączone: Biuro Prasowe Stolicy Apostolskiej, Watykańskie Służby Internetowe, Radio Watykańskie, Watykański Ośrodek Telewizyjny, dziennik „L’Osservatore Romano”, drukarnia (Tipografia Vaticana), Służby Fotograficzne oraz Watykańska Księgarnia Wydawnicza. Ponadto, w porozumieniu z Sekretariatem Stanu nowa instytucja będzie zarządzać oficjalną stroną internetową Stolicy Apostolskiej, a także papieskimi kontami i profilami na portalach społecznościowych ${ }^{29}$.

\footnotetext{
${ }^{28}$ Franciszek, Orędzie na Światowy Dzień Środków Społecznego Przekazu Komunikacja i Miłosierdzie - owocne spotkanie, 24 stycznia 2016, „L’Osservatore Romano” (wyd. pol.) 2 (2016), s. 8.

${ }^{29}$ Por. Franciscus, Litterae apostolicae motu proprio datae per l'istituzione della Segreteria per la Comunicazione L'attuale contesto comunicativo, 27 czerwca 2015, AAS 107 (2015), art. 1, 3.
} 


\subsection{Organizacja pracy Sekretariatu do spraw Komunikacji}

Mimo iż od reorganizacji Papieskiej Rady upłynęło już ponad dwa i pół roku, niewiele można powiedzieć o pracy samego Sekretariatu do spraw Komunikacji. Dopiero po szesnastu miesiącach od powołania do życia tej instytucji Papież Franciszek podpisał jej Statut normujący strukturę i kompetencje poszczególnych dyrekcji, które wchodzą w jej skład ${ }^{30}$.

Statut - określając naturę i kompetencje nowej dykasterii - widzi w niej organizm, który ma zjednoczyć wszystkie instytucje medialne działające obecnie przy Stolicy Apostolskiej i mogące pojawić się w przyszłości jako spójny system komunikacyjny, pozwalający pełnić misję ewangelizacyjną Kościoła we współczesnym świecie (por. art. 1). Swoje obowiązki powinna pełnić we współpracy z pozostałymi dykasteriami, a w szczególności z Sekretariatem Stanu (por. art. 2).

Strukturę Sekretariatu do spraw Komunikacji tworzą prefekt, sekretarz, członkowie, którymi powinni być zarów no duchowni, jak i świeccy różnego pochodzenia, będący ekspertami w dziedzinie komunikacji, oraz konsultorzy. Wszystkie te osoby są mianowane przez Biskupa Rzymu na pięcioletnie kadencje (por. art. 3). Członkowie mogą zostać wezwani do wyrażenia opinii w sprawach uznanych za ważne przez prefekta. Na sesjach zwyczajnych wystarczająca jest obecność członków przebywających na stałe w Rzymie, natomiast wszyscy powinni zbierać się na zebraniach plenarnych, które należy zwoływać przynajmniej dwa razy w roku (por. art. 4).

Dla sprawniejszego prowadzenia bardzo zróżnicowanej działalności medialnej, która ma dokonywać się pod auspicjami Sekretariatu, został on podzielony na pięć Dyrekcji, na czele których stoją dyrektorzy mianowani na pięcioletnie kadencje przez Biskupa Rzymu.

\footnotetext{
${ }^{30}$ Franciscus, Messaggio del Santo Padre Francesco per la L Giornata Mondiale delle Comunicazioni Sociali Comunicazione e misericordia: un incontro fecondo, 24 stycznia 2016, http://w2.vatican.va/content/francesco/it/messages/communications/documents/papa-francesco_20160124_messaggio-comunicazioni-sociali.html (dostęp: 15 luty 2017 roku).Tekst polski: FrAnCiszek, Orędzie na Światowy Dzień Środków Społecznego Przekazu Komunikacja i Miłosierdzie - owocne spotkanie, 24 stycznia 2016, „L'Osservatore Romano” (wyd. pol.) 2 (2016), s. 8.
} 
Nominacja dokonuje się na wniosek składany za pośrednictwem Sekretariatu Stanu przez prefekta Sekretariatu.

W obecnym kształcie Sekretariat składa się z: Dyrekcji ds. Ogólnych, Dyrekcji Wydawniczej, Dyrekcji Biura Prasowego Stolicy Apostolskiej, Dyrekcji Technicznej i Dyrekcji Teologiczno-Duszpasterskiej (por. art. 5).

\subsection{Szczegółowe kompetencje wydzielonych komórek}

Zadania poszczególnych jednostek, wchodzących w skład Sekretariatu, określa Statut w rozdziale III, poświęconym poszczególnym Dyrekcjom. Ich obowiązki kształtują się następująco:

a) Dyrekcja ds. Ogólnych - zarządzanie bieżącymi sprawami pozostałych czterech dyrekcji, administracja zasobami ludzkimi, czuwanie nad procedurami wewnętrznymi, ochrona praw autorskich, zarządzanie dobrami materialnymi Sekretariatu w celu zabezpieczenia środków potrzebnych do działalności medialnej poszczególnych podmiotów, koordynacja inicjatyw o charakterze międzynarodowym (por. art. 8).

b) Dyrekcja Wydawnicza - kierowanie i koordynacja wszystkich linii wydawniczych, pozostających w kompetencji Sekretariatu, strategiczny rozwój nowych form komunikacji, integracja mediów tradycyjnych ze „światem cyfrowym”, ze szczególnym uwzględnieniem uniwersalnego charakteru komunikacji ze strony Stolicy Apostolskiej (por. art. 9).

c) Dyrekcja Biura Prasowego Stolicy Apostolskiej - publikacja i rozpowszechnianie oficjalnych komunikatów dotyczących aktów podejmowanych przez Biskupa Rzymu i działalności Stolicy Apostolskiej, organizacja konferencji i briefingów prasowych, formułowanie, w porozumieniu z Sekretariatem Stanu, oficjalnych odpowiedzi na zapytania dziennikarzy dotyczących działalności Biskupa Rzymu, dykasterii Kurii Rzymskiej oraz innych instytucji watykańskich (por. art. 10).

d) Dyrekcja Techniczna - zintegrowane zarządzanie platformami i urządzeniami technicznymi koniecznymi do działalności Sekretariatu, rozwój środków komunikacji społecznej należących 
do Stolicy Apostolskiej, poszukiwanie nowych metod i rozwiązań zgodnych z nowoczesną technologią światową, projektowanie nowych środków oraz rozwój już istniejących, ze szczególnym uwzględnieniem uniwersalności komunikacji Stolicy Apostolskiej oraz zróżnicowanych warunków Kościołów partykularnych, określenie i aplikacja procesów zgodnych z obowiązującymi na polu technologicznym wytycznymi watykańskimi i międzynarodowymi, modernizacja rozwiązań praktycznych (por. art. 11).

e) Dyrekcja Teologiczno-Pastoralna - wypracowanie teologicznej wizji komunikacji, z uwzględnieniem przekazywanych treści, promocja aktywności duszpasterskiej Biskupa Rzymu przez słowa i obrazy w kontekście treści stojących u jej podstaw, promocja formacji teologiczno-duszpasterskiej w łączności z Kościołami partykularnymi oraz stowarzyszeniami działającymi na polu komunikacji, uwrażliwianie chrześcijan (szczególnie przy okazji celebracji Światowego Dnia Środków Społecznego Przekazu) na ogromne znaczenie środków komunikacji w przekazie doktryny chrześcijańskiej i dobra wspólnego (art. 12).

\subsection{Pracownicy i współpracownicy Sekretariatu do spraw Komunikacji}

Oprócz wyżej wymienionych osób tworzących strukturę Sekretariatu do spraw Komunikacji, jego pracę wspomaga dwunastoosobowa Rada. Jej zadaniem jest wypracowanie, pod kierunkiem prefekta i sekretarza, generalnych linii działalności nowej dykasterii. Oprócz wspomnianych dwóch urzędników, którzy stoją na czele Sekretariatu, w skład Rady wchodzą dyrektorzy poszczególnych dyrekcji i ich zastępcy. Prefekt, za pośrednictwem Sekretariatu Stanu, może zaproponować utworzenie innych jednostek, poza wymienionymi, które mogłyby wejść w skład Sekretariatu do spraw Komunikacji. Ich celem mogłaby stać się np. ochrona szczególnych wymogów prawnych, wydawniczych czy ekonomicznych, mogących pojawić się w działalności poszczególnych organizmów tworzących Sekretariat (por. art. 6). Uwzględniając pojawiające się okoliczności Rada 
może także dokonywać potrzebnych modyfikacji i zmian w pracy istniejących dyrekcji i odpowiedzialnych za poszczególne instytucje osób (por. art. 7). W swojej pracy Sekretariat musi dysponować odpowiednimi zasobami ludzkimi oraz materialnymi - proporcjonalnymi do pełnionych zadań. Personel i współpracownicy zewnętrzni powinni być wybierani spośród osób o dobrej reputacji, „wolnych od jakiegokolwiek konfliktu interesów” i posiadających odpowiedni stopień formacji i doświadczenia zawodowego (por. art. 13).

Szczególną wagę Statut Sekretariatu przywiązuje do ochrony dokumentów oraz materiałów i danych zarówno analogowych, jak i cyfrowych, będących w dyspozycji Sekretariatu w związku z pracą poszczególnych instytucji medialnych (por. art. 14-15).

\subsection{Normy przejściowe}

Zróżnicowana i obszerna działalność poszczególnych instytucji medialnych wchodzących w skład Sekretariatu do spraw Komunikacji oraz koordynacja działania nowej dykasterii wymaga czasu i zastosowania odpowiedniej procedury, która powinna być wdrażana stopniowo. W tym celu w rozdziale V Statutu zamieszczone zostały przepisy przejściowe.

Zasugerowane w nich rozwiązanie dotyczy stopniowego i „płynnego" przechodzenia kolejnych jednostek w skład Sekretariatu. Do czasu wchłonięcia jednostki przez nową dykasterię, powinna ona kierować się własnymi obowiązującymi dotychczas normami, jednakże z uwzględnieniem wskazówek formułowanych przez prefekta Sekretariatu. On także decyduje o sposobie i ostatecznej dacie wejścia w skład Sekretariatu poszczególnej jednostki. Po tej dacie instytucja zostanie zniesiona jako autonomiczny organizm. W procesie integracji należy przestrzegać dyrektyw, regulaminów i innych dyspozycji wydawanych sukcesywnie przez Sekretariat (por. art. 19).

Sekretariat do spraw Komunikacji jest zobowiązany do opracowania własnego regulaminu, według dyspozycji Ogólnego Regulaminu Kurii Rzymskiej (por. art. 17).

Statut Sekretariatu do spraw Komunikacji obowiązuje od 1 października 2016 roku przez trzy lata - ad experimentum (por. art. $19 \$ 4$ ). 
W nieuregulowanych w nim kwestiach należy aplikować przepisy prawa kanonicznego, szczególnie te, które definiują strukturę Kurii Rzymskiej, uwzględniając także wspomniany wyżej jej regulamin.

\section{Zakończenie}

Wraz z pojawieniem się nowego środka przekazu, jakim stał się film, i upowszechnieniem się na świecie kinematografii, w Kościele wzrastała świadomość i potrzeba zainteresowania się nowymi technologiami oraz stworzenia w ramach struktur Stolicy Apostolskiej instytucjonalnej ochrony wiernych przed szkodliwym wpływem niewłaściwych treści, a takżedla propagowania treści pożytecznych.

W tym celu już w 1948 roku powstała Międzynarodowa Komisja do spraw Konsultacji i Badania Filmów o Tematyce Religijnej, przekształcona kolejno w Papieską Komisję do spraw Kinematografii Dydaktycznej i Religijnej, a następnie w Papieską Komisję do spraw Kinematografii. W nurcie soborowych przemian, powołana wcześniej Papieska Komisja do spraw Kinematografii, Radia i Telewizji otrzymała uprawnienia w dziedzinie wszystkich środków komunikacji społecznej. Niemała w tym zasługa - powołanego do prac przedpoborowych - Sekretariatu Przygotowawczego Soboru dla Prasy i Widowisk.

Soborowa odnowa i wpływ dekretu Inter mirifica zaowocowały utworzeniem przy Stolicy Świętej Biura do spraw Środków Komunikacji Społecznej oraz struktur - na wzór papieskiej Komisji - na różnych poziomach kościelnych, na płaszczyźnie krajowej i międzynarodowej. Inter mirifica domaga się ponadto powołania krajowych biur do spraw mediów pod przewodnictwem komisji biskupiej lub oddelegowanego biskupa.

W 1964 roku papież Paweł VI dokonał kolejnej reformy, zmieniając Papieską Komisję do spraw Kinematografii, Radia i Telewizji w Papieską Komisję do spraw Komunikacji Społecznej i włączając ją w struktury Sekretariatu Stanu. Komisji powierzono ponadto troskę o Biuro Prasowe Stolicy Świętej oraz Filmotekę Watykańską.

Zapoczątkowana konstytucją apostolską Pastor Bonus Jana Pawła II reforma Kurii Rzymskiej dotknęła także struktury zajmujące 
się komunikacją społeczną. Powołana Papieska Rada Środków Społecznego Przekazu otrzymała nowe kompetencje i zadania, które realizowała przez blisko trzydzieści lat.

W ubiegłym roku Papież Franciszek dokonał radykalnej zmiany, powołując Sekretariat do spraw Komunikacji, który - obok Sekretariatu do spraw Gospodarczych - jest zupełnie nową strukturą Kurii Rzymskiej. Podobnie jak poprzedzające go instytucje do spraw komunikacji społecznej, w dalszym ciągu ma on współpracować w dziedzinie środków komunikacji społecznej z Sekretariatem Stanu, jednocząc w sobie wszystkie instytucje medialne Stolicy Apostolskiej, co jest zupełną nowością, ale jednocześnie niełatwym zadaniem. Zróżnicowana działalność Papieskiej Rady, Biura Prasowego Stolicy Apostolskiej, służb internetowych, radia i telewizji, prasy, drukarni, służb fotograficznych oraz Watykańskiej Księgarni Wydawniczej jest trudna do skoordynowania i może niekiedy prowadzić do konfliktu interesów, na co wskazuje sam Statut Sekretariatu (por. art. $13 \$ 2$ ), promulgowany ad experimentum, dopiero po szesnastu miesiącach istnienia Sekretariatu, o którego konkretnej działalności można - jak do tej pory - powiedzieć niewiele.

Należy żywić nadzieję, że zwrócenie szczególnej uwagi na nieocenione możliwości współczesnych środków komunikacji w realizacji misji Kościoła, przez powołanie nowej instytucji i próbę koordynacji za jej pomocą wszelkich wysiłków w dziedzinie komunikacji społecznej ze strony Stolicy Apostolskiej, rzeczywiście przyczyni się do skutecznego przepowiadania Ewangelii, dostosowanego do potrzeb i możliwości współczesnego odbiorcy.

\section{The reform of papal's institutions for social communication}

With the advent of a new medium which became the film and the spread of the cinematography all around the world, in the Church there was an increase of awareness and the need to take an interest in new technologies and to create within the framework of the Holy See the institutional protection of worshippers against the harmful impact of inappropriate content, as well as to propagate the useful content. 
For this purpose, over the years the special institutions were created, which in the structure of the Roman Curia were directly engaged in the media issues. Initially this task was undertaken by the Pontifical Commission, which for several years was subject to constant change (from 1948 to 1964), while from 1964 till 2015 we had to deal with the activities of the Pontifical Council for Social Communications.

The last reformatory accent in this field is the appointment by Pope Francis on the $27^{\text {th }}$ of June 2015 the Secretariat for Communication. Like the preceding institutions of social communication, it still has to collaborate in the area of the social communication with the Secretariat of State, uniting together all the media institutions of the Holy See.

SŁoWA KLUCzowe: komunikacja społeczna; środki społecznej komunikacji; Sekretariat do spraw komunikacji; Papieska Rada Środków Społecznego Przekazu

KEY WORDS: social communication; instruments of social communication; Secretariat for Communications; Pontifical Council for Social Communications

\section{Nota o Autorze:}

Ks. DR RAfaE Kamiński CSMA - adiunkt w Katedrze Kanonicznego Prawa Małżeńskiego i Rodzinnego na Wydziale Prawa Kanonicznego Uniwersytetu Kardynała Stefana Wyszyńskiego w Warszawie, obrońca węzła małżeńskiego Sądu Metropolitalnego Warszawskiego. 